\title{
OIL PRICE VOLATILITY AND INFRASTRUCTURAL GROWTH: EVIDENCE FROM AN OIL- DEPENDENT ECONOMY
}

\author{
Sunday Osahon Igbinedion \\ Department of Economics, Faculty of Social Sciences, University of Benin, Edo State \\ Nigeria \\ sunday.igbinedion@uniben.edu
}

\begin{abstract}
Since the discovery of crude oil in Nigeria in 1957, the Nigerian economy has remained a mono-product economy largely impacted by the effects of oil price volatility with its attendant adverse consequences on the nation's revenue profile and infrastructural growth. Accordingly, this paper attempts to investigate the nexus between oil price volatility and infrastructural growth in Nigeria, utilizing cointegration and error correction modeling approach for the period 1981-2015. The data for this study were sourced from the Central Bank of Nigeria Statistical Bulletin, 2014 and 2016 editions. The results suggest that both oil price volatility and inflation rate tend to exert negative impact on infrastructural growth, while the appreciation of real exchange rate tend to trigger investment in infrastructure. Accordingly, we recommend, among others, the need to design and implement effective diversification policies with a view to raising the nation's revenue trajectory, while strengthening local crude oil refining capacity so as to minimize the adverse consequences of such external shocks on the domestic economy.
\end{abstract}

Key Words: oil price, infrastructure, ECM, economic growth, Nigeria.

JEL classification: H54, L72, Q32, Q43.

\section{Introduction}

For several decades running, crude oil has evolved and still remains one of the single most crucial defining forces of the global economy, with oil prices becoming increasingly volatile since the end of the Second World War. In recent times however, the volatility in oil prices has become even more serious. Such oil price shocks (defined as sudden changes) have severe implications for the economies of oil-exporting nations, especially oil-dependent countries like Nigeria.

Nigeria is an open economy that has no real influence on the world price of oil, but is largely impacted by the effects of oil price volatility; more so, as a net importer of refined petroleum products. As observed by Rentschler (2013), positive volatility in oil prices affects the economy via different channels. Such positive increases impact on the private sector by raising costs of production and minimize outputs, while the final consumers may end up bearing part of such increases by way of price increases. Such developments may negatively impinge on macroeconomic indicators like employment, inflation and trade balance, among others.

However, the recent volatility (that is, large fall) in crude oil prices, which started in mid-2014, has adversely affected Nigeria in diverse ways, especially in the areas of infrastructural development, foreign reserves, currency crisis, declining government revenue and increasing cases of the nation's inability to meet its financial obligations as at when due. This development has therefore triggered a number of empirical studies on the nexus between such crude oil price volatility and a number of macroeconomic aggregates in Nigeria. However, many of such studies have either investigated the macroeconomic impact of oil 
price volatility (Omisakin, 2008; Ahuru and James, 2015), or examined the consequences of such oil price volatility on the growth of the Nigerian economy (Oriakhi and Osaze, 2013). Most of those empirical studies on the nexus between oil price instability and infrastructural growth have not only been outside the confines of the Nigerian economy, but also have been largely cross sectional in nature (Habibi, 1998; Hamdi and Sbia, 2013). One common problem associated with such cross sectional studies is that they tend to hide significant country specific features and dynamics. Second, the lumping of countries together in such studies (for instance, transition, developing, emerging, industrialized) with differing socio-economic configurations makes it difficult to understand the role of country-specific conditions across different time periods. Thus, replicating the policy recommendation(s) from such cross country studies for the Nigerian economy may be quite misleading.

Accordingly, this paper extends the current literature on oil price instability and its impact on infrastructural growth in a number of significant ways. First, unlike previous studies like Englama, Duke, Ogunleye and Ismail (2010) and Oriakhi and lyoha (2013), which employed the standard deviation as measurement of oil volatility, this study uses the generalized autoregressive conditional heteroskedasticity $(\mathrm{GARCH})$ measure of volatility with a higher predictive power. Second, this study utilizes data for a longer sample period than any other previous studies in this area, thus taking into consideration the various episodes of oil price shocks that have occurred over the years. Third, this study employs cointegration and error-correction methodology aimed at providing for both the long-run and short-run dynamics. Lastly, and to the best of the researcher's knowledge, this it he first attempt at specifically studying the link between oil price volatility and infrastructural growth within the Nigerian context.

The main goal of this research investigation is to empirically ascertain the linkage (if any) between oil price volatility and infrastructural growth in Nigeria with a view to providing informed policy prescriptions aimed at minimizing the perceived negative impact of such oil price variability on the nation's revenue trajectory and, by extension, on the projected level of infrastructural growth in the country.

The remainder of this paper is structured as follows. Section 2 provides a review of related empirical literature, while section 3 provides the methodological framework and data for the study. Section 4 presents the results and discusses the findings. Section 5 concludes the paper with relevant policy prescriptions.

\subsection{The Dynamics of Oil Price and Infrastructural Growth}

Over the years, the Nigerian economy has witnessed significant swings (fall and rise) in the prices of crude oil in the international oil market, with attendant consequences on the economy. According to Hamilton (1983) and Wakeford (2006), such fluctuations often result from changes in either the demand or supply side of the international oil prices. In all, the Nigerian economy has witnessed six (6) phases of oil price shocks. These are the oil price shocks of 1973-74; 1979-80; 1986; 2003-2006, 2008-2009 and 2014. Meanwhile, while those of 1973-74, 1979-80 and 2003-2006 were characterized by increases in the price of oil per barrel and, by extension, a rise in government revenue, those of 1986, 2008-2009 and 2014 were episodes marked by the plummentation of oil price. For instance, during the first oil price shock of 1973-1974, the price of oil per barrel rose from $\$ 2.19$ in 1971 to about $\$ 11.58$ by the close of 1974 , representing about 48 percent rise. The second oil price shock (rise) of $1979-80$ period saw the price of oil per barrel rising from about $\$ 14.12$ in January 1979 to about $\$ 38.82$ by the end of 1980, a percentage increase of about 175 (Obadan, 2010).

Meanwhile, the other three episodes of oil price decline of 1986, 2008-2009 and 2014 were marked not only by huge fall in the price of oil per barrel (attaining its minimum level in 
annual average term in 2016), but also in terms of exports receipts and fiscal revenue, with attendant consequences on the average growth of the economy.

On the other hand, Nigeria's level of infrastructure (measured by gross fixed capital formation, GFCF) has fluctuated widely over the years. For instance, the country's GFCF, which stood at N133.22 billion in 1981 declined to N40.93, N40.12 and N29.83 in 1985, 1990 and 1995 respectively. It however declined to its lowest level of N6.3 billion in 2001 . Thereafter, it rose to N142.32 in 2014, before attaining its highest peak of N2608.06* in 2015 (Central Bank of Nigeria Statistical Bulletin 2014, 2016). The import of the foregoing is that both levels of oil price and infrastructure have experienced wide swings over the years, a development that has adverse consequences on the growth of the domestic economy.

Note: * Central Bank of Nigeria computed GFCF values from $1980-2014$ using 1990 as its base year, while GFCF values from 2015 till date have 2010 as their base year.

\section{Review of Related Literature}

In economic literature, infrastructure (whether physical or social) has been indentified as a veritable ingredient in the development process of any nation. According to Ogbuozobe (1997), the term infrastructure describes a network of transport, communication and public (social) services all working as a system or as a set of interrelated beneficial services provided for the improvement of the general well-being of the population. Specifically, good and adequate infrastructure not only help to raise the level of productivity, facilitates the realization of potential human capital, but also improves safety and quality of human lives which, ultimately, helps promotes the overall growth and development of the economy.

As stated in the introductory section, there has been an avalanche of empirical studies linking oil price volatility to macroeconomic performance or some components thereof (e.g exchange rate, domestic price, investment), but only a handful of such studies directly regressed infrastructural growth/development on oil price volatility. In what follows, we briefly review some of such related studies (both country specific and cross-sectional studies).

Habibi (1998) investigated the impact of changes in oil revenue on budgetary decisions using a panel data for five (5) Middle-Eastern oil-exporting countries. His finding reveals that while budget shares of defence and economic affairs and services were positively correlated to oil export revenue, those of social expenditures were inversely correlated, suggesting that the latter, being important politically, is often protected against volatility in oil revenues.

El Anshasy (2009) examined the impact of oil price volatility on economic growth for a panel of fifteen (15) oil exporters during the period 1970-2004. The results reveal, among others, that oil price shocks are not harmful to the long-run growth of those economies after all.

In a related study, Akinlo and Apanisile (2015) investigated the impact of oil price volatility on economic growth in twenty (20) sub-Saharan African countries for the period 1986-2012, using panel data. The result revealed in part that, volatility of oil price has a positive and significant effect on the economic growth of those oil exporting nations.

Aziz and Dahalan (2015) on their part attempted to ascertain the asymmetric effects of oil price shocks on real economic activities in ASEAN - 5 nations for the period 1991-2014, using an unrestricted panel vector autoregressive (VAR) method. The result suggests that increases in oil price negatively affects economic activities in both the short and long-runs. With reference to country-specific studies, Jawad (2013) analyzed the impact of oil price volatility on the economic growth of Pakistan for the period, 1973-2011, employing linear regression analysis. The result revealed that oil price volatility has insignificant impact on the level of economic growth during the period under focus. In another study, Hamdi and Sbia (2013) empirically examined the dynamic relationship between oil revenues, government spending and economic growth in Bahrain for the period 1960-2010, using a trivariate 
cointegration and error-correction approach. The result indicates that, oil revenue remains the prime-mover of the economy, via government spending.

Oriakhi and lyoha (2013) employed the VAR methodology to investigate the consequences of oil prices volatility on the growth of the Nigerian economy for the period 1970-2010. The result shows that changes in oil price tend to impact on the growth of the economy via government expenditure.

In a similar study, Donwa, Mgbame and Onobun (2015) examined the relationship between oil price volatility and the growth of the Nigerian economy. The results suggests that volatility in oil prices are the major cause of the nation's unstable growth rate over the years. Tehranchian and Seyyedkolaee (2017) studied the impact of oil price volatility on economic growth in Iran for the period 1980-2014, using the threshold regression model. The result indicates that oil price volatility tends to significantly impact on economic growth, even though such impact tend to diminish over time.

\section{Methodological Framework and Data}

\subsection{Data}

This study utilizes annual data covering the period 1981 to 2015 sourced from the Central Bank of Nigeria (CBN) Statistical Bulletin and the National Bureau of Statistics (NBS) (various issues). This period (1981-2015) was chosen because of the non-availability of data on some of the variables of interest. The variables are oil price volatility (OILPV), gross fixed capital formation (GFCF), inflation rate (INFL), real exchange rate (REXCH) and interest rate (INTR).

A measure of oil price variability was obtained by employing the generalized autoregressive conditional heteroskedasticity $(\mathrm{GARCH})$ approach, which models volatility as conditional on past behaviour (see Bollerslev, 1986). The best fitting time series GARCH $(1,1)$ model was determined on the basis of Akaike Information Criteria (AIC).

\subsection{Theoretical Framework}

Within the economic growth literature, there are quite a number of growth theories attempting to establish the relationship between oil price volatility and the macro economy or some parts thereof. In what follows, we attempt to briefly highlight three (3) of such theories, namely the Linear/symmetric relationship theory of growth, the Asymmetry-in-effect theory of economic growth, and the Renaissance growth theory.

The Linear/Symmetric relationship theory of growth posits that an inverse relationship exists between oil price volatility and the GDP growth within the US economy. Following the pioneering work of Hamilton (1983), others such as Hooker (1996) observed that $0.6 \%$ decline in GDP growth was associated with a $10 \%$ rise in oil price. Similar conclusions were arrived at for the US economy by Laser (1987) and Rotemberg and Woodford (1996). On their part Lee, Ni and Ratti (1995) submitted that such sudden and unanticipated oil price growth has had a highly significant and asymmetric effects not only on output but also on other macroeconomic variables, as well as on personal incomes and other forms of earnings.

The Asymmetry-in-effect theory of economic growth postulates that decreases in oil prices tend to have little or no appreciable effects on the economic activities in the US as well in some OECD nations. (Hanilton, 1996; Mork 1989; Mory, 1993; Ferderer, 1996 and Herrera, et al, 2010). Mork (1989) for instance investigated the asymmetric response of oil price volatility by decomposing oil price changes in real price increases and decreases. The result reveals that oil price decreases is significantly different and perhaps zero. Lee et al (1995) 
study also confirmed the asymmetry in effects in the period before and after 1985, and the issue of whether or not such asymmetry effect is a function of their variables.

Ferderer (1996) in explaining the asymmetric mechanism between oil price volatility and economic activity considered three possible channels, namely, counter-inflationary monetary policy, sectoral shocks and uncertainly. He observed that asymmetric monetary policy responses partly explains the asymmetric oil price -output relationship.

The Renaissance growth theory was a by-product/fall-out of the symmetric and asymmetric effects of oil price volatility and the macro-economy. This theory attempts to establish the relative effects of oil price changes and oil price volatility on economic growth for a given period of time. In this regard, Lee (1998) revealed that though both effects impact negatively on economic growth, the effects of changes in oil prices tend to thin out after one year. As such, he submitted that, it is volatility in crude oil prices rather than prices in oil level that has a lasting and appreciable effect on economic growth on the long-run (Lee, 1998).

\subsection{Model Specification}

Drawing from the reviewed literature (such as Oriakhi and lyoha, 2013) and the theoretical underpinnings, we hypothesize a simple model where gross fixed capital formation (GFCF), (a proxy for infrastructural development), is specified as a function of a number of relevant regressors, like oil price volatility, inflation rate, real exchange rate and interest rate.

GFCF $=\lambda_{0}+\lambda_{1}$ OLPV $+\lambda_{2}$ INFL $+\lambda_{3} \mathrm{REXCH}+\lambda_{4}$ INTR $+\alpha$

Where:

OLPV $=$ Oil price volatility

GFCF $=$ Gross fixed capital formation (a proxy for infrastructural development)

$\mathrm{REXCH}=$ Real exchange rate

INFL = Inflation rate

INTL = Lending interest rate (a proxy for monetary lending rate).

The analytical tools used for this study include, correlation matrix, stationarity test, cointegration and error-correction mechanism, among others.

\section{Results and Discussion}

\subsection{Descriptive Analysis}

Table 1a presents the variables used in the estimation and their characteristics. The Jarque-Bera statistic rejects the null hypothesis of normal distribution for gross fixed capital formation (GFCF) and inflation (NFL). On the other hand, the null hypothesis of normal distribution is accepted for oil price volatility (OLPV), real exchange rate (REXCH) rate and interest rate (INTL). Also, while the distribution of GFCF INFL and INTR are leptokurtic, those of OLPV and REXCH are platykurtic in nature.

From the correlation matrix in Table 1b, GFCF shows a strong positive relationship with OLPV (64\%) and EXCH (72\%) but a negative correlation with INFL (-29\%) and INTL $(-0.09 \%)$. Oil price volatility (OLPV) shows a positive correlation with GFCF $(64 \%)$ and EXCH $(0.40 \%)$, but a negative relationship with INFL (-39\%) and INTR (-54\%). Similarly, INFL has a positive correlation with INTR (37\%), but negatively correlated with GFCF $(-0.29 \%)$ OLPV (-39\%) and EXCH (-41\%). 
Oradea Journal of Business and Economics, Volume IV, Issue 1

Published on March 2019

Table 1a: Descriptive Statistics

\begin{tabular}{|l|l|l|l|l|l|}
\hline Metrics & GFCF & OLPV & INFL & REXCH & INTR \\
\hline Mean & 23031105 & 3462.245 & 19.71465 & 71.40880 & 17.80657 \\
\hline Median & 2422563. & 1893.981 & 12.21701 & 22.06540 & 17.79500 \\
\hline Maximum & $1.36 \mathrm{E}+08$ & 9607.157 & 72.83550 & 192.4405 & 31.65000 \\
\hline Minimum & 87994.80 & 553.4797 & 5.382224 & 0.617708 & 8.916667 \\
\hline Std. Dev. & 41747196 & 2781.638 & 17.93583 & 66.18510 & 5.038503 \\
\hline Skewness & 1.739342 & 0.748135 & 1.626154 & 0.225740 & 0.174328 \\
\hline Kurtosis & 4.329452 & 2.184212 & 4.372112 & 1.349790 & 3.426492 \\
\hline Jarque-Bera & 20.22516 & 4.235492 & 18.17112 & 4.268583 & 0.442540 \\
\hline Probability & 0.000041 & 0.120302 & 0.000113 & 0.118328 & 0.801500 \\
\hline
\end{tabular}

Source: Author's Computation using E-view 8.0

Table 1b: Correlation Matrix

\begin{tabular}{|l|l|l|l|l|l|}
\hline Metrics & GFCF & OLPV & INFL & EXCH & INTR \\
\hline GFCF & 1.000000 & 0.642335 & -0.288207 & 0.718192 & -0.088370 \\
\hline OLPV & 0.642335 & 1.000000 & -0.390758 & 0.400715 & -0.537543 \\
\hline INFL & -0.288207 & -0.390758 & 1.000000 & -0.408312 & 0.369669 \\
\hline EXCH & 0.718192 & 0.400715 & -0.408312 & 1.000000 & 0.160573 \\
\hline INTR & -0.088370 & -0.537543 & 0.369669 & 0.160573 & 1.000000 \\
\hline
\end{tabular}

Source: Author's computation using E-view 8.0

\subsection{Testing for Stationary}

In economic literature, most macroeconomic time series data are non-stationary, and employing such non-stationary variables in empirical investigations might produce spurious results and, by extension, misleading policy prescriptions (Granger and Newbold, 1977). As such, we investigated the time-series properties using the Augmented Dickey-Fuller (ADF) and Phillips-Perron (PP) tests, and the results are as presented in Table 2. The results shows that all variables used in the study are 1 (I) variables, that is, stationarity was attained after first difference in both the ADF and PP test procedures.

Table 2: ADF and PP Unit Root Tests

\begin{tabular}{|l|l|l|l|l|l|}
\hline VARIABLES & $\begin{array}{l}\text { ADF } \\
\text { STATISTIC }\end{array}$ & $\begin{array}{l}\text { CRITICAL } \\
\text { VALUE }\end{array}$ & $\begin{array}{l}\text { PHILIPS } \\
\text { PERRON }\end{array}$ & $\begin{array}{l}\text { CRITICAL } \\
\text { VALUE }\end{array}$ & $\begin{array}{l}\text { ORDER OF } \\
\text { INTEGRATION }\end{array}$ \\
\hline GFCF & -4.588692 & -2.954021 & -4.562502 & -2.954021 & $1 / 1$ \\
\hline OLPV & -8.135257 & -2.954021 & -7.978101 & -2.954021 & $1 / 1$ \\
\hline INFL & -5.956310 & -2.957110 & -8.583237 & -2.954021 & $1 / 1$ \\
\hline EXCH & -5.219976 & -2.954021 & -5.217650 & -2.954021 & $1 / 1$ \\
\hline INTR & -6.415554 & -2.954021 & -6.425948 & -2.954021 & $1 / 1$ \\
\hline
\end{tabular}

Source: Author's Computation using E-view 8.0

\subsection{Testing for Cointegration}

Basically, cointegration tests are designed to test for the existence of long-run equilibrium between the variables in the model, as this is vital for the purpose of policy making.

In order to ascertain the existence or otherwise of a stable long-un relationship among the variables under focus, this study adopts the methodology developed by Johansen (1988), and Johansen and Juselius (1990). This approach is expected to produce asymptotically optimal estimates because it incorporates a parametric correction mechanism, and it does not depend on the methods of normalization chosen.

Following the approach by Johansen and Juselius (1990), two likelihood test statistics, the Max-Eigen and Trace tests were utilized to derive the number of cointegrating vectors. The cointegrating tests were performed allowing the absence of linear trends. 
From the cointegration results in Table 3, max-eigen and trace statistics reject the null hypothesis of no cointegration at the $5 \%$ level. Specifically both statistics confirm the existence of one cointegrating equation among the variables. This confirms the convergence property, hence an error-correction model is presented.

Table 3: Johanson Co-integration Test Results

\begin{tabular}{|l|l|l|l|l|l|}
\hline $\begin{array}{l}\text { Null } \\
\text { Hypothesis }\end{array}$ & Eigenvalue & $\begin{array}{l}\text { Trace } \\
\text { statistic }\end{array}$ & $\begin{array}{l}\text { Critical value } \\
\text { at 5 percent }\end{array}$ & $\begin{array}{l}\text { Max-Eigen } \\
\text { statistic }\end{array}$ & $\begin{array}{l}\text { Critical value } \\
\text { at 5 percent }\end{array}$ \\
\hline$\alpha=0$ & 0.749114 & $75.27957^{*}$ & 60.06141 & $45.63092^{*}$ & 30.43961 \\
\hline$\alpha \leq 1$ & 0.464559 & 29.64866 & 40.17493 & 20.61390 & 24.15921 \\
\hline$\alpha \leq 2$ & 0.155737 & 9.034754 & 24.27596 & 5.586605 & 17.79730 \\
\hline$\alpha \leq 3$ & 0.087016 & 3.448148 & 12.32090 & 3.004222 & 11.22480 \\
\hline$\alpha \leq 4$ & 0.013362 & 0.443927 & 4.129906 & 0.443927 & 4.129906 \\
\hline
\end{tabular}

Notes: $\alpha$ Represents at most the number of cointegrating equations.

*Denotes significance at the $5 \%$ level.

Source: Author's Computations using E-view 8.0.

\subsection{The Error Correction Model}

Following Engle and Granger (1987), if cointegration exists between non-stationary variables, then an error-correction representation of the kind specified by equation (2) exists for these variables. Essentially, the error-correction term (ect) in equation (2) enables us to gauge the speed of adjustment of equilibrium once the equation is shocked or distributed.

Below is the dynamic error correction formulation:

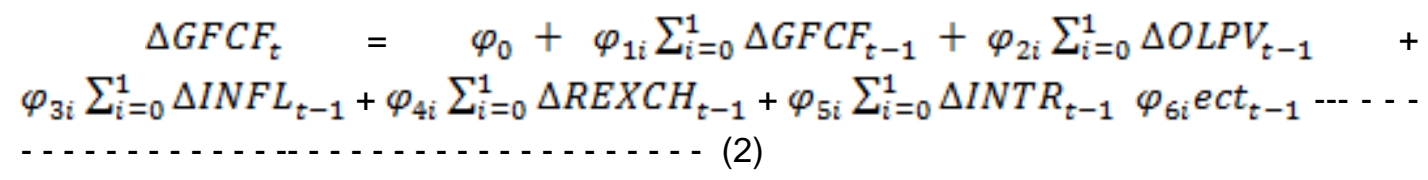

Where:

ect is the error correction term, and " $\Delta$ " represents the difference of a series, $\varphi_{0}, \ldots \ldots ., \varphi_{6}$ are parameters of the model to be estimated. The "i" represents the number of lags included for the first time difference of both the dependent variables while t represents the time period. All other variables are as previously defined in equation (1).

Table 4 contains the results of the estimated error-correction model. Following Enders (1995), ordinary least squares (OLS) will give consistent estimates, provided the variables included in the model are stationary.

Results contained in Table 4 show that the coefficient of the error-correction term for the estimated infrastructural growth equation is correctly signed and statistically significant at $5 \%$ level of significance. The speed of convergence to long-run equilibrium is $76.92 \%$. This result indicates that about 77 percent of the short-run disequilibrium in infrastructural growth (GFCF) is corrected each period (year). This high rate of convergence is of much practical use in policy analysis, and in decision making (Pesaran, 1997). Besides, this is vital for maintaining long-run equilibrium to reduce the existing disequilibrium over time. 
Oradea Journal of Business and Economics, Volume IV, Issue 1

Published on March 2019

Table 4: Estimated Short-run regression result for gross fixed capital formation

\begin{tabular}{|c|c|c|c|c|}
\hline \multicolumn{5}{|c|}{ Dependent Variable: (DGFCF) } \\
\hline \multicolumn{5}{|c|}{ Sample (adjusted): 19822015} \\
\hline \multicolumn{5}{|c|}{ Included observations: 34 after adjustments } \\
\hline Variable & Coefficient & Std. Error & t-Statistic & Prob. \\
\hline C & 3695972. & 1956124. & 1.889436 & 0.0692 \\
\hline DOILPV & -2355.986 & 1142.789 & -2.061611 & 0.0486 \\
\hline DINFL & -16531.53 & 7714.257 & -2.142984 & 0.0473 \\
\hline $\mathrm{DEXCH}$ & 18460.99 & 6747.055 & 2.736155 & 0.0327 \\
\hline DINTR & -96309.25 & 82764.93 & -1.163648 & 0.4712 \\
\hline $\mathrm{ECM}(-1)$ & -0.769251 & 0.374294 & -2.055200 & 0.0493 \\
\hline R-squared & 0.891613 & & & \\
\hline Adjusted R-squared & 0.865116 & & & \\
\hline Akaike info criterion & 35.32450 & & & \\
\hline Schwarz criterion & 35.59386 & & & \\
\hline F-statistic & 2.305288 & & & \\
\hline Prob(F-statistic) & 0.031216 & & & \\
\hline Durbin-Watson stat & 1.990945 & & & \\
\hline
\end{tabular}

Source: Author's computation using E-view 8.0

The coefficient of oil price volatility is negatively and statistically significant at $5 \%$ level, confirming extant findings that crude oil price volatility (especially negative shocks) tend to inhibit infrastructural growth and, by extension, the level of investment in the domestic economy (Habibi, 1998; Farzanegan and Markwardt, 2009; Jbir and Ghorbel, 2009; Ebrahim and Mohammad, 2012; Dizaji, 2014). This calls for the need to implement policies aimed at stabilizing the effects of such negative shocks on infrastructural growth in the economy. The coefficient of inflation is negative and statistically significant at $5 \%$ level. Thus, a one percent increase in inflation level will cause the level of infrastructure to decline by about 165 percent in Nigeria. This is not unexpected because high inflation, especially when associated with increased price instability, often raise the level of uncertainty about the future profitability of investment projects thereby lowering the overall level of investments especially in infrastructure.Similarly, the coefficient of interest rate is negative but statistically insignificant.

Finally, the slope coefficient of real exchange rate is positive and statistically significant at 5 percent level of significance. Specifically, a one percent increase in exchange rate will cause the level of infrastructure to rise by about 184 percent in Nigeria. Such real exchange rate appreciation may encourage investment in infrastructure (especially, fixed investment) by lowering the relative prices of imported machinery and equipment. The implication of such real exchange appreciation is to shift relative prices in favour of non-tradables, bringing about a reallocation of both labour and investment away from the production of tradeable goods and services.

\subsection{Stability Test}

In this study, we utilized the approach developed by Brown, Durbin and Evans (1975) to investigate the short-run stability of the parameters in the infrastructural growth model using the plots of the cumulative sum of the residuals (CUSUM) and the cumulative sum of squares of recursive residuals (CUSUMSq). It should be noted that, whilst the CUSUM test is particularly useful for dectecting systematic changes in the regression coefficients, the CUSUMSq test is significant in situations where the departure from the constancy of regression coefficients is haphazard and sudden. The results from the two tests are presented in figures $1(\mathrm{~A})$ and $1(\mathrm{~B})$ respectively. Essentially, the existence of parameter 
instability is established if the CUSUM of the residuals and the CUSUM of squares of the residuals go outside the bands represented by the two critical lines (dotted lines). From the graphs in figures $1(A)$ and $1(B)$, the CUSUM remains within the 5 percent critical line throughout the period under consideration, thus indicating parameter stability throughout that period of estimation. The CUSUM of squares on the other hand is found to veer off the critical line between 1993 and 2013, indicating parameter instability within that period.

Parameters Stability Test

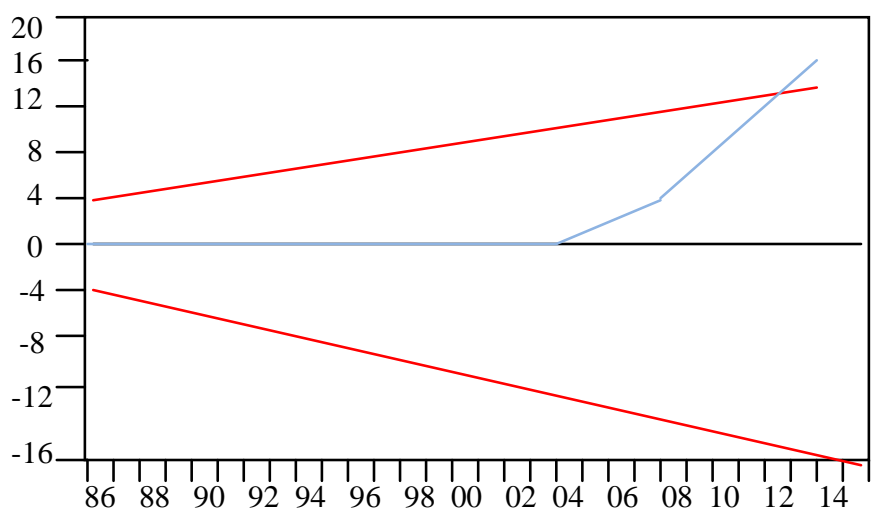

Figure 1(a): Cumulative Sum of Recursive Residual (CUSUM) Source: Author's computation, using E-views 8.

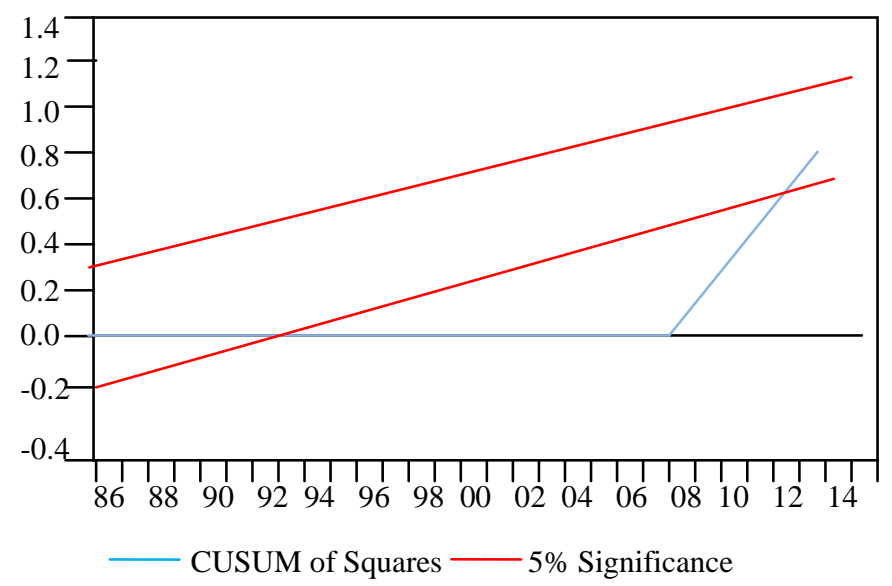

Figure 1(b): Cumulative Sum of Squares of Recursive Residual (CUSUMsq) Source: Author's computation, using E-views 8.

\section{Conclusion and Policy Recommendations}

This study investigated the nexus between oil price volatility and infrastructural growth in Nigeria within the context of Johansen cointegration and error correction framework, applying annual data from 1981-2015. Results from the study reveal that volatility in oil price is negative and statistically significant, while that of interest rate was also negative but statistically insignificant. Also, inflation exerted a negative and statistically significant impact on infrastructural growth. Specifically, a one percent-increase in inflation rate caused the 
level of infrastructure to decline by about 165 percent. However, an appreciation in the level of real exchange rate tends to trigger investment in infrastructure, especially in fixed investment.

Based on the above findings, the work concludes that the quantum of investment in infrastructure development in Nigeria is not only low, but unstable, given the volatile nature of the price of the nation's foreign exchange earner (oil). Thus, if economic infrastructure is to adequately promote the growth performance of the economy, then complementary sources of finance must be identified and harnessed with a view to raising expenditure on infrastructure stock to the internationally recommended benchmark of 70 percent of the GDP as against the estimated 35 percent of GDP in 2018 (Centre for the Study of Africa (CSEA), (2018).

Arising from the foregoing findings, we make the following specific policy recommendations. First, there is the urgent need to design and implement effective diversification policies aimed at increasing the production of exportable goods with a view to raising the nation's revenue profile and cushion the economy's vulnerability to oil price volatility, thereby engendering sustainable infrastructural growth in the country. Such policies should be complemented by strengthening local crude oil refining capacity, with a view to further minimizing the consequences of such external shocks, and partly by improving the requisite regulatory environment so as to promote more public-private partnership in the provision of economic infrastructure. Second, the relevant authorities should put in place policies aimed at maintaining low inflation rates in order to boost infrastructural growth and trigger higher economic growth. Lastly, given the likelihood that appreciation in real exchange rate may not significantly impact on all categories of infrastructure, the authorities concerned should put in place appropriate exchange rate regime aimed at promoting investment in infrastructure in the long-run.

\section{Limits of the Research}

(a) Unavailability of up-to-date data for the research. For instance, data for 2016 and 2017 for some of the variables were not available.

(b) The use of GFCF as a proxy for infrastructure is in adequate, considering the fact that the term infrastructure embraces a broad spectrum of facilities like (is GFCF a good proxy for infrastructure?)

\section{References}

Ahuru, R.R and James, U.E. 2015. Macroeconomics of oil price volatility Journal of Research in National Development (JORIND), 13(1) June, pp. 253-262.

Akinlo, T. and Apanisile, O.T. 2015. The impact of volatility of oil price on the economic growth in sub-Saharan Africa. British Journal of Economics, Management and Trade, 5(3), pp. 338-349.

Aziz, M.I.A. and Dahalan, J. 2015. Oil price shocks and macroeconomic activities in Asean-5 countries: A panel VAR approach. Eurasian Journal of Business and Economics, 8(16), pp. 101-120.

Bollerslev, T. 1986. Generalized autoregressive conditional heteroskedasticity. Journal of Econometrics, 31, pp. 307-327

Brown, R.I. Durbin, J. and Evans, M. 1975. Techniques for testing the constancy of regression relationships overtime. Journal of the Royal Statistical Society, 37, pp. 149-163. Central Bank of Nigeria (CBN) Statistical Bulletin, 2014, Vol 25, December.

Central Bank of Nigeria (CBN) Statistical Bulletin, 2016 Vol. 27, December

Centre for the Study of Africa (CSEA) 2018. Nigeria Economic Update, Issue 32, August 10. 
Dizaji, S.F. 2014. The effects of oil shocks on government expenditures and government revenues nexus (with an applications to Iran's sanctions). Economic Modeling, 40, pp. 299-313.

Donwa, P.A., Mgbame, C.O. and Onobun, S.I. 2015. Oil price volatility and economic growth. Journal of Business Administration and Management Sciences Research, 4(5), pp. 98-104.

Ebrahim, E. and Mohammad, A.A. 2012. Asymmetric impacts of oil prices and revenue fluctuation on selected macroeconomic variables in Iran. Journal of Basic and Applied Scientific Research, 2(8), pp. 7930-7937.

El Anshasy, A.A. 2009. Oil prices and economic growth in oil-exporting countries. Proceedings of the $32^{\text {nd }}$ the International Association of Energy Economics (IAEE) Conference 2009.

Enders, W. 1995. Applied Econometric Time Series New York: John Wiley.

Englama, A. Duke, O.O; Ogunleye, T.S. and Ismail, F.U. 2010. Oil prices and exchanges rate volatility: An empirical investigation. Central Bank of Nigeria, Economic and Financial Review, 48(3), pp. 31-48.

Engle, R. F. and Granger, C. W. J. 1987. Cointegration and error correction: Representation, estimation and testing. Econometrica, 55, pp. 391-407.

Farzanegan, M.R. and Markwardt, G. 2009. The effects of oil price shocks on the Iranian economy. Energy Economics, 31(1), pp. 134-151.

Ferderer, J. 1996. Oil price volatility and the macroeconomy. Journal of Macroeconomics, 18(2), pp. 1-26.

Granger, C.W.J. and Newbold, P. 1977. Time series approach to econometric model building, In: C.A. Sims (ed.), New Methods in Business Cycle Research: Proceedings from Conference, Federal Reserve Bank of Minneapolis.

Habibi, N. 1998. Fiscal response to fluctuating oil revenue in oil exporting countries of the Middle East. ERF Working Paper Series No. 0136.

Hamdi, H. and Sbia, R. 2013. Dynamic relationships between oil revenues, government spending and economic growth in an oil-dependent economy. Economic Modeling, 35, pp. 118-125.

Hamilton, J. 1996. This is what happened to the oil price-macroeconomy relationship? Journal of Monetary Economics, 3(2), pp. 215-220.

Hamilton, J.D. 1983. Oil and the macro economy since World War II. The Journal of Political Economy, 91, pp. 228-248.

Herrera, A.M., Lagalo, L.G. and Wada, T. 2010. Oil price shocks and industrial production: Is the relationship linear? Macroeconomic Dynamics, 15,S3, pp 492-497.

Hooker, C. 1986. Effects of oil price and exchange rate variations on government revenue in China: Journal of Economics, 2(1), pp. 2-13.

Jaward, M. 2013. Oil price volatility and its impact on economic growth in Pakistan. Journal of Finance and Economics, 1(4), pp. 62-68.

Jbir, R. and Ghorbel, S.Z. 2009. Recent oil price shock and Tunisian economy. Energy Economics, 37, pp. 1041-1051.

Johansen, S. and Juselius, K. 1990. Maximum likelihood estimation and inference on cointgration with applications to the demand for money. Oxford Bulletin of Economics and Statistics, 52, pp. 169-210.

Johansen, S. 1988. Statistical analysis of cointegrating vectors. Journal of Economic Dynamics and Control, 12, pp. 231-254.

Laser, Y. 1987. Interest, inflation, growth and the direction of the Hong-Kong economy. Chinese Economic Review 120(3), pp. 74-86.

Lee, K. 1998. Oil price changes and volatility: A correlation analysis on the economy of China. Scholarly writers publications, 15(4), pp. 44-49. 
Lee, K., Ni, S. and Ratti, R. 1995. Oil shocks and the macroeconomy: The role of price variability Energy Journal,16, pp. 39-56.

Mork, K.A. 1989. Oil and the macroeconomy when prices go up and down: An extension of Hamilton's results. Journal of Political Economy, 97, pp. 740-744.

Mory, J.F. 1993. Oil prices and economic activity: Is the relationship symmetric? The Energy Journal, 14(4), pp. 151-162.

National Bureau of Statistics (NBS) (Various Issues).

Obadan, M.I. 2010. Nigeria at 50 and its national economic development paradigms: The benefit of hind sight. A lecture delivered at the occasion of Nigeria's $50^{\text {th }}$ Independence Anniversary at the Auchi Polytechnic, Auchi.

Ogbuozobe, J.E. 1997. Infrastructural Development in Nigeria in 2010, In: Phillips, A. and Titilola, S.T. (eds.), Nigerian Institute of Social and Economic Research (NISER); pp. 163-193.

Omisakin, A.O. 2008. Oil price shocks and the Nigerian economy: A forecast error variance decomposition analysis. Journal of Economic Theory, 2(4), pp. 124-130.

Oriakhi, D.E and lyoha, D.O. 2013. Oil price volatility and its consequences on the growth of the Nigerian economy: An examination (1970-2010). Asian Economic and Financial Review 3(5), pp. 683-702.

Pesaran, M. H. 1997. The role of economic theory in modeling the long-run. The Economic Journal, 10, pp. 178-191.

Rentschler, J.E. 2013. Oil price volatility, economic growth and the hedging role of renewable energy. World Bank Policy Research Working Paper 6603.

Rotemberg, J.J. and Woodford, M. 1996. Imperfect competition and the effects of energy price increases on economic activity. Journal of Money, Credit and Banking, 28, pp. 549-577.

Tehranchian, A.M. and Seyyedkolaee, M.A.2017. The impact of oil price volatility on the economic growth in Iran: An application of a threshold regression model. International Journal of Energy Economics and Policy, 7(4), pp. 165-171.

Wakeford, J. 2006. The impact of oil price shocks on the South African macro economy: History and prospects. South African Reserve Bank Conference, Pretoria, South Africa.

\section{Bionote}

Sunday Osahon Igbinedion is a Senior Lecturer in the Department of Economics, Faculty of Social Sciences, University of Benin, Nigeria. His main research fields are international finance, econometrics, health economics and energy economics. He has published about 45 academic articles (20 in peer-review international journals), authored two academic books. Dr. Igbinedion is in the editorial board of five national and two international journals. 